\title{
Market Structure of Sago Starch in Southeast Sulawesi, Indonesia
}

\author{
HAJI SAEDIMAN ${ }^{1 *}$, HELVIANI HELVIANI ${ }^{2}$, LAILA REFIANA SAID ${ }^{3}$, SARINAH SARINAH $^{4}$, \\ SITTI AIDA ADHA TARIDALA ${ }^{1}$, LA ODE ALWI ${ }^{1}$, ILMA SARIMUSTAQIYMA RIANSE ${ }^{1}$, \\ ${ }^{1}$ Department of Agribusiness, Faculty of Agriculture, Halu Oleo University. Kendari, \\ INDONESIA \\ ${ }^{2}$ Department of Agribusiness, Faculty of Agriculture, Fisheries and Animal Husbandry, \\ Sembilanbelas November University, Kolaka, \\ INDONESIA \\ ${ }^{3}$ Department of Management, Faculty of Economics and Business, Lambung Mangkurat University, \\ Banjarmasin, \\ INDONESIA \\ ${ }^{4}$ Department of Food Science and Technology, Faculty of Agriculture, Halu Oleo University, Kendari, \\ INDONESIA
}

\begin{abstract}
Sago plant produces sago starch, which can be processed into various food and non-food uses and has high demand in the domestic and international market. However, sago starch marketing is still facing problems that make the crop has not yet optimally support the economy of sago growing and processing households and communities. The study aimed to assess the market structure of sago starch in Konawe District of Southeast Sulawesi Province, Indonesia. Data collection was done in two sago growing subdistricts. Respondents consisted of 55 sago producers, four subdistrict collectors, and two large traders. Data were collected using questionnaires, observation, and in-depth interviews, and were analyzed using Concentration Ratio and descriptive statistics. Study results showed that market participants consisted of producers, collectors, large traders, and retailer. The producer or seller concentration was low, and the atomistic selling condition prevailed in the sago extraction industry. The market share of the four largest collectors was $67.25 \%$. Product differentiation was not present or low among the sago producers. Observed barriers to entry into the sago starch production included lack of technical skills, availability of water sources, knowledge of the area, and the nature of sago extraction operation. Barriers to entry into sago marketing were moderate and included capital requirement, economies of scale, knowledge of the area, and networking with both producers and large traders. The sago starch market has deviated from the norms of competitive market structure, namely, an oligopsonistic market structure. The structural features of the industry need to be improved by establishing standard and grades to facilitate marketing and to lead to product differentiation.
\end{abstract}

Key-Words: marketing, market structure, producer, sago, starch, Indonesia

Received: October 28, 2020. Revised: March 3, 2021. Accepted: March 16, 2021. Published: April 2, 2021.

\section{Introduction}

Sago palm is a plant that originated from New Guinea Island [1], and it grows in many areas in Indonesia. Sago plant produces starch, which is an essential foodstuff in the sago growing communities. Sago starch also has a vast potential for utilization in various industries, such as in the food and non-food industry, biotechnology, and other industries [2]. This versatile utilization of sago starch leads to its high demand in the domestic and international market. Consequently, there have been changes in the sago extraction or harvesting technologies, from traditional technology to semimechanized and modern technologies. Semimechanized technology uses sharing wage labor and processing machines that can be moved from one place to another. Mechanized technology uses wage labor and large machines, which is immobile [3]. Along with such changes in extraction technology, sago farmers or sago tree owners no longer process their sago trunks; instead, they sell sago boles to sago extraction groups $[4,5]$. They then use the money to buy food and non-food needs [6]. 
In Southeast Sulawesi, sago is one of the four main staple foods, with the other three being rice, maize, and cassava [7,8]. People in Southeast Sulawesi, especially Tolakinese, have consumed sago for generations. Sago starch is commonly consumed in the form of sinonggi, which is prepared by adding hot water over the starch and stirring it until it coagulates and becomes the gluelike sticky dough. Along with staple food diversification efforts and perceived benefits of sago-based foods, sinonggi is increasingly popular in the province [9]. The increasing popularity of sago as a local staple food indicates its significant opportunity in the food industry sector. Increased demand for sago starch in the food and non-food sectors requires the development of sago agroindustry. At the same time, the development of sago agroindustry is needed in the efforts to enhance food security and villagers' welfare [10], and to support the development of the economy of the local communities [5]. Promoting food security through diversification of staples, including sago, has received growing attention recently as the efforts to attain rice self-sufficiency has faced challenges such as human population growth, stagnant rice production, climate change [11-13], land conversion, and crop or livelihood shift $[14,15]$. Food security is also affected by international trade [16].

According to Naim [6], three key players essential in the functioning and sustainability of the sago industry are sago processing enterprise, local market, and local food industry. Sago processing enterprises or factories buy sago trees from sago tree owners or farmers and process sago trunks to produce wet sago starch. The wet sago starch is sold to consumers in the various local markets, or shipped to other areas outside the province [17]. The households and the local food industry purchase sago starch at the local market. These three components act as providers for sago tree owners or sago farmers to sell their sago trees, and sago producers to sell their sago starches [17]. However, the effective functioning of the three players requires effective marketing linkages [18] and an efficient marketing system that can provide just returns to all actors involved in the marketing chain.

Marketing activities are essential for sago farmers and producers to increase their income. However, sago marketing is still facing problems that make the crop does not optimally support the economy of sago growing and processing households and communities. Studies by Saediman et al. [19] found that sago marketing problems included characteristics of sago production systems, the lack of institutional supports, inadequacy of infrastructure, quality control, the lack of market information, and the lack of knowledge on marketing. Altogether, these problems led to a weak bargaining position of sago farmer-producers, making them price takers rather than price makers.

Several studies dealt with various aspects of sago marketing [9,19-22]. However, studies about market structure of sago starch are lacking. The present study attempts to examine the market structure of sago starch. Specifically, the study was undertaken to attain the following two objectives: (a) identify the market participants in sago marketing, and (b) analyze the market structure of sago starch in Konawe District of Southeast Sulawesi. The knowledge and information gained from this study will contribute to the literature about sago marketing and assist endeavours to promote its role in food security, poverty alleviation, and community development.

\section{Materials and Methods}

The study was conducted in Sampara and Besulutu subdistricts, Konawe District, Southeast Sulawesi. Konawe District is situated between the latitude $2^{\circ} 45^{\prime}$ and $4^{\circ} 15^{\prime}$ South, and the longitude $121^{\circ} 15^{\prime}$ and $123^{\circ} 30^{\prime}$ East. The district has a size of 5,799 $\mathrm{km}^{2}$ and consists of 29 subdistricts. The study locations were purposively selected because they were the significant sago producing areas in the district and had the potential for further development. All producers operating in the two subdistricts and being accessible were taken as respondents for this study, namely, 30 producers in Besulutu and 25 producers in Sampara subdistrict. Respondents for traders were selected using snowball sampling, involving marketing institutions along the supply chain from collectors until large traders and retailers. Data analysis used market share, concentration ratio, and descriptive statistics. Market share ranges from $0-100 \%$, and reflects the firm's output against the total output in the industry. The concentration ratio is calculated based on the market share of the largest four firms [23] using the following formula:

$$
\begin{aligned}
& \mathrm{CR} 4=\sum_{i-1}^{4} \mathrm{~S} i j \\
& \text { Where: } \\
& \mathrm{S}_{\mathrm{ij}} \quad=\text { The percentage market share of the } \\
& \text { four largest firms } \\
& \text { CR4 = Concentration ratio of the four } \\
& \text { largest firms }
\end{aligned}
$$


The average monthly output of each sago extracting or harvesting group did not show considerable variation, so the concentration ratio was calculated only at the collector level. In this regard, the value of CR4 was calculated for the four largest collectors in Besulutu and Sampara Districts. CR4 denotes the amount of output produced by the four largest collectors against the total sago volume in the Besulutu and Sampara Districts. The criteria for CR4 value used the indicators proposed by Buzzelli [24] as follows:

$\begin{array}{ll}<25 \% & : \text { Low, atomistic } \\ 25-50 \% & : \text { Moderate, loose oligopoly } \\ >50-75 \% & : \text { High, oligopoly } \\ >75-100 \% & : \text { Very high, tight monopoly }\end{array}$

Based on the Buzzeli's classification, CR4 less than $25 \%$ indicates low concentration or atomistic. A loose oligopoly with moderate concentration exists when CR4 ranges from $25 \%$ to $50 \%$. High concentration or oligopoly occurs with CR4 higher than $50 \%$ until $75 \%$. An industry is in tight monopoly and is considered a very high concentration when CR4 is more than $75 \%$.

\section{Results and Discussion}

\subsection{Market Participants}

Market participants consisted of sago producers, collectors, large traders, and retailer. Producers conduct sago extraction or harvesting to produce sago starch. Harvesting takes place through several steps, namely, (1) selection and felling of sago trees, (2) log debarking and splitting, (3) rasping to break down the pith, (4) extracting starch, (5) sedimentation and dewatering, and (6) drying, packaging, and storage [25]. Harvesting operation is done collectively by a group of several people using some equipment, such as a chainsaw, rasper, and pump [1]. Sago produced is generally in the form of wet sago starch. Prices of wet sago starch ranged from $\mathrm{Rp} 1,600 / \mathrm{kg}$ to $\mathrm{Rp} 1,800 / \mathrm{kg}$, depending on the agreement between the producer and the trader.

Collectors bought sago starch from sago producers and sold it to large traders. To obtain sago starch, the collectors had to take sago to extraction locations, which were sometimes far from the main road and difficult to access. Sometimes producers took the starch to the main road where collectors came and collected it. Price negotiation with producers was conducted before or after collectors arrived at the extraction locations.

Large traders purchased wet sago starch from collectors and then shipped it to the buyers outside the province. Based on the observations and interviews with respondents, it was found that there were five large traders in the provincial capital. In this regard, the large traders are also the interregional traders as they ship sago starch to the industrial buyers in Java through containers. To ensure that they get a large quantity of sago starch, they build strong ties and develop trust with collectors who can regularly supply sago starch. Large traders sometimes proactively purchase sago starch directly at the extraction sites, and sometimes from other collectors in the district.

Retailer sold sago starch to the end consumers at the local market. It was revealed during the field survey that all producers sold their wet sago starch to collectors and large traders, and only one producer sold sago starch at the local market.

\subsection{Market Structure}

Market structure is the organizational characteristics of the market that determine the relationship between sellers and buyers [26]. For this study, the dimensions or salient aspects of the market structure were assessed from (a) the extent of market concentration, (b) the extent of product differentiation, and (c) the condition of entry of the market.

\subsubsection{Market Concentration}

Market concentration deals with the number of buyers and sellers and their relative size distribution in a market [27]. Higher market concentration is believed to reflect a non-competitive behavior and inefficiency. The most commonly used measure of the market concentration is the market concentration index, which measures the percentage of traded volume of products accounted for by a given number of participants. The market concentration consists of the extent of seller concentration and the extent of buyer concentration. In this regard, sago producers are sellers, while collectors and large traders are buyers.

The degree of producer concentration refers to the number of producers in the sago industry, and to the relative sizes of producers with any given number [26]. The degree of producer concentration can be calculated based on the sales volume, namely, the share of total sales or production accounted for by the four largest firms in the industry. However, sales volume per month did not show considerable variation from one producer to another. The average production was seven tons per month [5] with a maximum of ten tons per month. Since there were many small-scale producers, the four largest producers would not have significant market share. The four firms' concentration ratio for one month during the study period was less than $25 \%$, meaning that the four largest firms controlled 
less than $25 \%$ of the market. These producers were large in number, small in size, and located scattered throughout the two subdistricts. Each enterprise produced a small amount of sago starch, and it could not influence the price either by limiting its production or by negotiating with collectors. Based on these features, it was clear that there was no evidence of seller concentration and rather atomistic selling condition prevailed in the industry. Buzzelli [24] denominated the industry with CR4 less than $25 \%$ as atomistic. Hence based on Buzzeli's classification, it can be concluded that the sago extraction industry in Konawe District exhibits a low atomistic market structure.

Concerning collectors and large traders as the buyers of sago starch, their concentration can be calculated from the market share of the four largest traders. As Table 1 shows, the total sales volume of wet sago starch by the four largest collectors in one month during the study was 153 tons, which was $67.25 \%$ of the total sales volume of 228 tons per month. This means that sago marketing's four-firm concentration ratio at collector level is $67.25 \%$. Based on Buzzelli's classification of CR4 value, the market structure of sago marketing in the study area exhibits a high oligopsony, namely, a market with only a few buyers.

Table 1. CR4 value of collectors

\begin{tabular}{|c|c|c|}
\hline Collector & Sales volume (ton) & Market share (\%) \\
\hline 1 & 39 & 17.03 \\
2 & 48 & 20.96 \\
3 & 38 & 16.81 \\
4 & 28 & 12.45 \\
\hline Total & 153 & 67.25 \\
\hline
\end{tabular}

The market share of each large trader was not calculated, so the CR4 value for the large traders was unknown. However, since there were only five large traders in the province that purchased wet sago starch in all districts within the province, it was highly likely that their CR4 would be more than $50 \%$. Based on Buzzeli's classification, CR4 more than $50 \%$ indicates oligopoly or oligopsony. Therefore, it could be concluded that the market structure of sago starch from the standpoint of the large traders was also high oligopsony.

\subsubsection{Product Differentiation}

The degree of product differentiation is the extent to which collectors differentiate, distinguish or have special preferences among the competing starch of the various producers [26]. Sources of the differentiation can be (i) differences in the quality of starch, (ii) packaging and relative prices, (iii) sales promotion services, (iv) brand of the product, and (v) location of the processing sites [28].

Based on field survey results, almost all respondents mentioned that product differentiation was not present or low in the sago starch industry. Unlike the traditional sago extraction process, which was inefficient, semi-mechanized processing increased the quantity and quality of sago starch. However, the starch quality was relatively similar from one producer to another. The reasons were that the technologies were relatively similar among the producers, and all producers depended on naturally grown sago trees. While both sago tree owners and producers were aware of the genetic variation of the sago trees [29], the most important aspects taken into account during sago tree price negotiation were trunk diameter, water content of soil in the growing sites, and the number of trees available to be harvested. Sago grown in extended waterlogged soil was regarded to have less starch content. As such, sago tree characteristics and growing environment might be different from one place to another, making it hard for producers to maintain consistency in sago starch quality.

The locations of the processing sites were mostly mobile, and few processing enterprises were permanent in specific locations. Sago plants grow in scattered areas, and those who bought the sago trees usually conducted sago extraction in the location where the plants grow. Therefore, producers could conduct sago harvesting in different areas. From the buyers' viewpoint, the extraction or harvesting location was not a source of differentiation of sago starch.

Sago producers did not use any branding to their sago starch produced. This might be related to the level of processing technology being used and varied types of sago plants being extracted, leading to the difficulty in producing sago starch with consistent quality. Besides, for sago producers with non-permanent extraction sites, the quality of water will be different among the sites, which will affect the consistency of the quality of sago starch. Inferiority and variation in starch quality have been sources of complaints in the international market [30]. More importantly, sago collectors and large traders did not require specific qualifications for their starch; they would purchase any sago starch being produced. This is related to the fact that there were no standards and grades employed for sago starch in the study area. The local utilization of sago mostly for consumption as staple food in the form of sinonggi, which is not dependent on the quality of the starch, is probably one reason. In contrast, the more advanced utilization for industrial purposes 
outside the province may require standards and grades. At the industry level, there could be grades of dry starch [31]. For these reasons, producers do not have to provide branding for their produced starch.

Producers did not use a specific method or material for packaging. At the end of the sago harvesting stage, the produced sago starch cake is removed and packaged using flour sacks or flour bags. The produce was usually sold soon after harvest, so there was no need for more extended storage.

The absence of product differentiation can be seen from the absence of buyers' preference toward the product of a particular producer to that of other producers. Some collectors sometimes differentiated the sago starch from its color and determined the price, but they did so primarily based on their own assessment as there were still no standards and grades of sago starch. In such a case, producers were in the low bargaining position and hence just took the price.

\subsubsection{Barriers to Entry}

The condition of entry determines the competitive relationships between established firms and potential entrant firms. The condition of entry to the industry is an indication of the presence of barriers to entry to that industry. Barriers to entry discourage entry decision of firms into the market [32]. Barriers to entry are some sources of disadvantages to potential entrants as compared with established firms. In general, there are three types of barriers to entry, namely; (i) economies of scale advantages of established firms over new entrant firms, (ii) absolute cost advantages of established firms over new entrant firms, and (iii) product differentiation advantages of established firms over new entrant firms [28]. In addition, government policies can also raise some barriers to entry. Among such policies are the grant of licenses, the regulation of price and entry, and taxation policy.

Semi-mechanized technology in sago harvesting is mobile and uses sharing labor. As mentioned previously, product differentiation was not present, so it could not become a barrier to entry. It was revealed from the study results that lack of technical skills, availability of water sources, knowledge of the area, and the nature of sago extraction operations are some barriers to entry for producers. Technical skills are related to managing processing operations, which are usually related to the length of experience in doing the work. The availability of water sources is essential because the sago harvesting operation requires water to wash the crushed pith. The quality of water can determine the quality of starch, particularly its color and smell [33]. Sufficient knowledge of the area is needed for the new entrants as they should purchase sago trees or sago boles from sago farmers or sago owners living in the villages in the two subdistricts. Sago growing locations themselves are spread over in various areas where sometimes there are issues of inaccessibility and poor basic infrastructure to the growing sites. The nature of sago extraction operation, which is time-consuming and laborious, might also pose a barrier for new entrants.

In the longer term, access to raw material could become barriers to entry and constraint for the sustainability [34] of sago harvesting business. The reason is that there are still no noticeable efforts from the local government, private sector, farmers, and other stakeholders to plant sago trees. The present sago cutting for sago starch production relies entirely on naturally grown sago trees. Therefore, the speed of sago tree cutting by sago producers might have exceeded the natural regrowth of sago plant. In addition, there has been a continued loss of sago plants due to their conversion to other purposes, such as rice farming, oil palm plantation, and housing. Consequently, the farmers or sago tree owners may someday increase sago tree prices [3]. If this happens, it will be difficult to sustain the sago industry because established sago producers or potential new-entrants need more cash to cover the operational cost, or may have to operate below their optimum capacity.

It should be noted that common barriers to entry such as non-availability of capital, lack of technology, and economies of scale [3,35-37] did not apply in the sago harvesting business. Sago harvesting operation using mobile semi-mechanized technology does not require huge amount of capital. Sago processing machine and tools are accessible. Sago harvesting operation is financially feasible for traditional, semi-mechanized, and mechanized processing technology $[3,38]$.

Barriers to entry at the collector level include a capital requirement, economies of scale, and networking with producers and large traders. Capital requirement is mainly for purchasing wet sago starch and vehicles. Networking and good relationship with producers and large traders are needed to ensure the sufficiency of sago starch to be purchased and to ensure its market. Economies of scale can become an entry barrier as the potential marketed volumes from producers were limited or remained the same despite an increase in the number of collectors. As such, the unit cost may rise as the number of collectors increases [27]. This in turn 
would naturally limit the number of collectors operating in the area with low trade volumes.

Barriers to entry at the large trader level include a capital requirement, economies of scale, trust and relationship with producers, and knowledge of and networking with the industrial buyer in Java. Huge capital is needed to finance investment and operational costs. In most cases, huge capital requirement involves taking loan from banks [39] and the use of shipping insurance service to protect the traders against any damage for the goods [40]. The economies of scale are essential as the shipment to Java should be done in a large amount using containers. Mutual trust and good relationship have been established between large traders and collectors. However, the knowledge of the market and networking with industrial buyers in Java is probably the most substantive entry barrier. As Cay et al. have noted, meeting customer demands requires companies to adapt to technology and develop innovation strategies [41].

From the previous description of barriers to entry, it can be said that entry barriers are different at the production and marketing levels. Generally, barriers to entry are lower in the sago starch production level and become higher as the product goes into the next stage in the supply chain. Given a low degree of producer concentration, a high degree of collector concentration, a high degree of large trader concentration, absence of product differentiation, and the existence of entry barriers, the sago starch market has deviated from the norms of competitive market structure. For these reasons, the sago starch market has an oligopsonistic market structure, namely, a market with only a few buyers. Buyers in an oligopsony have more power to determine prices, which could have implications to reduced profit margin for the producers.

\section{Conclusion}

The sago industry was exhibiting oligopsony with a highly concentrated market structure. In sago production, atomistic selling conditions prevailed, product differentiation was absent, and there were low entry barriers. Barriers to entry into sago production included technical skills, availability of water sources, knowledge of the area, and the nature of the sago extraction process. In sago marketing, there was a high degree of collector concentration, a high degree of large trader concentration, absence of product differentiation, the existence of moderate entry barriers at collector level, and high entry barriers at the large trader level. Sago extraction plays a significant role in the development of sago starch and flour industry. The structural features of the industry need to be improved by establishing standards and grades that can lead to product differentiation. In the longer term, access to raw material could become barriers to entry as (i) there have been conversion from sago growing plots to other purposes, and (ii) sago cutting for sago starch production relies entirely on naturally grown sago trees. Therefore, long-term access to raw materials should be sustained by adopting policies that apply integrated approach from up-stream to downstream agribusiness and supporting institutions.

\section{Acknowledgment}

The authors wish to thank Prof. La Rianda for his useful suggestions and comments during the preparation and implementation of this study.

\section{References}

[1] Y. Nishimura, "Sago starch: transformation of extraction and consumption processes in traditional Indonesian societies," in Sago palm: multiple contributions to food security and sustainable livelihoods, $\mathrm{H}$. Ehara, Y. Toyoda, \& D.V. Johnson (eds.), Singapore: Springer Open, 2018, pp. 221-229.

[2] A.A. Karim, A.P. Tie, D.M.A. Manan, \& I.S.M. Zaidul. Starch from the Sago (Metroxylon sagu) palm tree- properties, prospects, and challenges as a new industrial source for food and other uses. Comprehensive Reviews in Food Science and Food Safety, Vol.7, No.3, 2008, pp. 215-228.

[3] W. Girsang. "Feasibility of Small-Scale Sago Industries in the Maluku Islands," in Sago palm: multiple contributions to food security and sustainable livelihoods, H. Ehara, Y. Toyoda, \& D.V. Johnson (eds.), Singapore: Springer Open, 2018, pp. 109-121.

[4] Surni, M. Kamaluddin, \& A.M. Padangaran. "Analisis kelayakan usaha pengolah sagu Lameuru di Provinsi Sulawesi Tenggara." Prosiding Hasil-hasil Penelitian Sosek Fakultas Pertanian UGM, 2016. pp. 233-239.

[5] Surni, A.M. Padangaran, T. La Ola, \& H. Saediman. Determinants of value addition in sago processing in Southeast Sulawesi, Indonesia. IOSR Journal of Agriculture and Veterinary Science, Vol.11 No.12, 2018, pp.3438.

[6] H.M. Naim, A.N. Yaakub, A.N, \& D.A.A. Hamdan. Commercialization of sago through estate plantation scheme in Sarawak: The way forward. International Journal of Agronomy, 
Article ID 8319542, Vol. 2016, 6 pages, 2016, doi: $10.1155 / 2016 / 8319542$

[7] H. Saediman, Prioritizing commodities in Southeast Sulawesi Province of Indonesia using AHP based borda count method, Asian Social Science, Vol 11 No. 15, 2015, pp. 171179.

[8] H. Saediman, A. Amini, R. Basiru, \& L.O. Nafiu, Profitability and Value Addition in Cassava Processing in Buton District of Southeast Sulawesi Province, Indonesia, Journal of Sustainable Development. Vol. 8, No. 1, 2015, pp. 226-234.

[9] S.A.A. Taridala, H. Saediman, \& I. Merdekawati. "Pemasaran sagu (Metroxylon sp.)." Prosiding Seminar Nasional Menggagas Kebangkitan Komoditas Unggulan Lokal Pertanian dan Kelautan. Fakultas Pertanian Universitas Trunojoyo Madura. pp. 202-211, 2013.

[10] H. Saediman, M.A. Limi, Rosmawaty, P. Arimbawa, \& Y. Indarsyih. Cassava consumption and food security status among cassava growing households in Southeast Sulawesi, Pakistan Journal of Nutrition, Vol.15, No.12, 2016, pp.1008-1016.

[11] H. Saediman, S. Aisa, M. Zani, M.A. Limi, \& W.O. Yusria. Food security status of households in a cassava growing village in Southeast Sulawesi, Indonesia. Journal of Agricultural Extension. Vol.23, No.1, 2019a, pp.199-209.

[12] M. Zani, H. Saediman, S. Abdullah, L. Daud, \& L. Yunus, Determinants of Household Food Expenditure in a Cassava Growing Village in Southeast Sulawesi, Academic Journal of Interdisciplinary Studies. Vol. 8, No. 3, 2019, pp. 302-310.

[13] H. Saediman, L.O. Lasmin, M.A. Limi, U. Rianse, \& L. Geo, Rice Farmers' Perception of Climate Variability in South Konawe District of Southeast Sulawesi, International Journal of Scientific and Technology Research, Vol. 9, No. 2, 2020, pp. 3128-3132

[14] H. Saediman, Mustika, L. Nalefo, M. Tufaila, \& M. Zani. Cost and returns analysis of rice farming and brick making in South Konawe District of Southeast Sulawesi, International Journal of Scientific Technology and Research, Vol.8, No.10, 2019b, pp.835-838.

[15] S. Surni, H. Saediman, F. Wulandari, M. Zani, L. Yunus, \& S.A.A. Taridala, Profitability and constraints of small-scale tomato production in Baubau municipality of Southeast Sulawesi,
WSEAS Transaction on Environment and Development. Vol. 16, 2020, pp. 219-225.

[16] T.D. Ly, P.X. Dong, L.H. Anh, \& P.T.H. An, The Effect of International Trade on Food Security at Southeast Asian Countries. WSEAS Transactions on Environment and Development, Vol 16, 2020, pp.180-188

[17] A.M. Padangaran, Surni, T. La Ola, \& H. Saediman. Factors affecting the efficiency of sago marketing in Southeast Sulawesi, Indonesia, IOSR Journal of Agriculture and Veterinary Science, Vol.12, No.3, 2019, pp.5558.

[18] M.B. Dastagiri, B.G, Kumar, C.V. Hanumanthaiah, P. Paramsivam, R.S. Sidhu, M. Sudha, S. Mandal, B. Singh, \& K. Chand, K. Marketing efficiency of India's horticultural commodities under different supply chains. Outlook on AGRICULTURE, Vol.41, No.4, 2012, pp.271-278.

[19] H. Saediman, S.A.A. Taridala, \& M. Ono, M. Sago marketing practices and problems: A survey of two sago growing villages in Southeast Sulawesi. Agriplus, Vol.16, No.1, 2006, pp.1-7.

[20] N.R. Timisela, Analisis usaha sagu rumah tangga dan pemasarannya. Jurnal Agroforestry, Vol.1, No.3, 2006, pp.57-64.

[21] N. Azizah. Analisis strategi pemasaran sagu kasbi pada Gapoktan Prima Jaya di Kelurahan Jaya Kecamatan Tidore Utara Kota Tidore Kepulauan Provinsi Maluku Utara. Jurnal Ilmiah Agribisnis dan Perikanan (agrikan UMMU-Ternate), Vol.5, No.2, 2012, pp.83-92.

[22] I. Djamaluddin \& S. Sahala, (2018). Analisis margin pemasaran industri sagu Al-hidayah di Kelurahan Kintom Kecamatan Kintom Kabupaten Banggai, Jurnal Pendidikan, Sosial dan Budaya, Vol. 4 No. 3, 2018, pp. 248-258.

[23] R.L. Kohls \& J.N. Uhl. Marketing of Agricultural Products. Sixth edition, New York: Macmillan Publishing Co. Inc.. 1985

[24] M. Buzzelli. Firm size structure in North American housebuilding: persistent deconcentration 1945-98. Environment and Planning A, Vol. 33 No.3, 2001, pp. 533-550.

[25] Darma. "Improvement of sago processing machinery." In Sago palm: multiple contributions to food security and sustainable livelihoods, H. Ehara, Y. Toyoda, \& D.V. Johnson (eds.), Singapore: Springer Open, 2018. pp. 231-245.

[26] J.S. Bain, Industrial Organization. Second Edition. New York: John Wileyand Sons. Inc. 1968 
[27] G. Dessalegn, T.S. Jayne, \& J.D. Shaffer, Market structure, conduct, and performance: constraints on performance of Ethiopian Grain Markets. Working Paper 8, Ministry of Economic Development and Cooperation. Addis Ababa. 1998.

[28] M.D. Hossain \& M.S. Haque, Market structure of poultry hatchery industry in Bangladesh. $J$. Bangladesh Agril. Univ. 2(1): 2004, pp. 187195.

[29] B. Abbas. Sago palm genetic resource diversity in Indonesia," in Sago palm: multiple contributions to food security and sustainable livelihoods, H. Ehara, Y. Toyoda, \& D.V. Johnson (eds.), Singapore: Springer Open, 2018, pp. 61-71.

[30] T.C. Sunarti, V. Derosya, \& I. Yuliasih, "Acid modification of sago hampas for industrial purposes," in Sago palm: multiple contributions to food security and sustainable livelihoods, H. Ehara, Y. Toyoda, \& D.V. Johnson (eds.), Singapore: Springer Open, 2018, pp. 271-281.

[31] R.S. Singhal, J.F. Kennedy, \& S.M. Gopalakrishnan, Industrial productionprocessing, and utilization of sago palmderived product. Sci Direct Carbohydr Polym, Vol. 72, 2008, pp. 1-20.

[32] A. Sönmez, Firm entry, survival, and exit. Academic Journal of Interdisciplinary Studies. Vol. 2, No. 9, 2013, pp. 160-167

[33] F. Rumalatu, Sago in Maluku: Past, Present, and Future Prospect, Cakalele, vol. 3, 1992, pp. 63-68.

[34] H. Saediman, L.O. Alwi, I.S. Rianse, S.A.A. Taridala, S. Salahuddin, Y. Indarsyih, \& R.W. Astuti, Comparative Profitability of Melon and Watermelon Production in South Konawe District of Southeast Sulawesi. WSEAS Transactions on Business and Economics, Vol. 17, 2020, pp. 933-939.

[35] A.W. Gichangi. Analysis of Structure, conduct and performance of sweet potato marketing: the case of Nairobi and Kisumu, Kenya, Doctoral dissertation, Egerton University, 2010.

[36] J.W. Hanekom, B.J. Willemse, \& D.B. Strydom. Structure, conduct and performance in the South African Potato Processing Industry. Paper presented at the Joint 3rd African Association of Agricultural Economists $(A A A E)$ and 48th Agricultural Economists Association of South Africa (AEASA) Conference, Cape Town, South Africa, September 19-23, 2010
[37] D.T. Bosena, F. Bekabil, G. Berhanu, \& H. Dirk, H. Structure-Conduct-Performance of cotton market: The Case of Metema District, Ethiopia. Journal of Agriculture, Biotechnology \& Ecology, Vol. 4, No. 1, 2011, pp. 1-12.

[38] Asnani, Surni, \& H. Saediman, Analisis kelayakan finansial usaha pengolahan sagu di Desa Walasolo Kecamatan Asera Kabupaten Konawe Utara, Jurnal Ilmiah Membangun Desa dan Pertanian, Vol 4, No. 5, 2019, pp. 134-138.

[39] H. Meshref, Predicting Loan Approval of Bank Direct Marketing Data Using Ensemble Machine Learning Algorithms, International Journal of Circuits, Systems and Signal Processing, Vol. 14, 2020, pp. 914-922.

[40] X. Duan, Systematic Risk Measurement Based on CoVaR Model, International Journal of Circuits, Systems and Signal Processing, Volume 13, 2019, pp. 243-250.

[41] D. Cay, N. Goker, \& M. Dursun, Modelling R\&D Strategy to Fulfil Customer Demands through Digital Transformation, WSEAS Transactions on Business and Economics, Volume 16, 2019, pp.525-531

\section{Creative Commons Attribution License 4.0(Attribution 4.0 International ,CC BY 4.0)}

This article is published under the terms of the Creative Commons Attribution License 4.0 https://creativecommons.org/licenses/by/4.0/deed.en US 